\title{
Effect of Four Irrigation Regimes and Different Fertilizers on Vegetative Growth and Fruit Parameters of Eggplant (Solanum melongena L.)
}

\author{
Mahmud Ali1 ${ }^{1, a,}$, Cafer Gençoğlan ${ }^{2, b}$, Serpil Gençoğlan ${ }^{2, c}$ \\ ${ }^{I}$ Department of Bioengineering and Sciences, Institute of Science, University of Kahramanmaraş Sütçü Imam, 4605 Kahramanmaraş, Turkey \\ ${ }^{2}$ Department of Biosystem Engineering, Faculty of Agriculture, University of Kahramanmaraş Sütçü Imam, 4605 Kahramanmaraş, Turkey \\ *Corresponding author
}

\begin{tabular}{|c|c|}
\hline A R T I C L E I N F O & A B S T R A C T \\
\hline $\begin{array}{l}\text { Keywords: } \\
\text { Eggplant } \\
\text { Drip irrigation } \\
\text { Fertilizer } \\
\text { Plant growth components } \\
\text { Fruit variables }\end{array}$ & 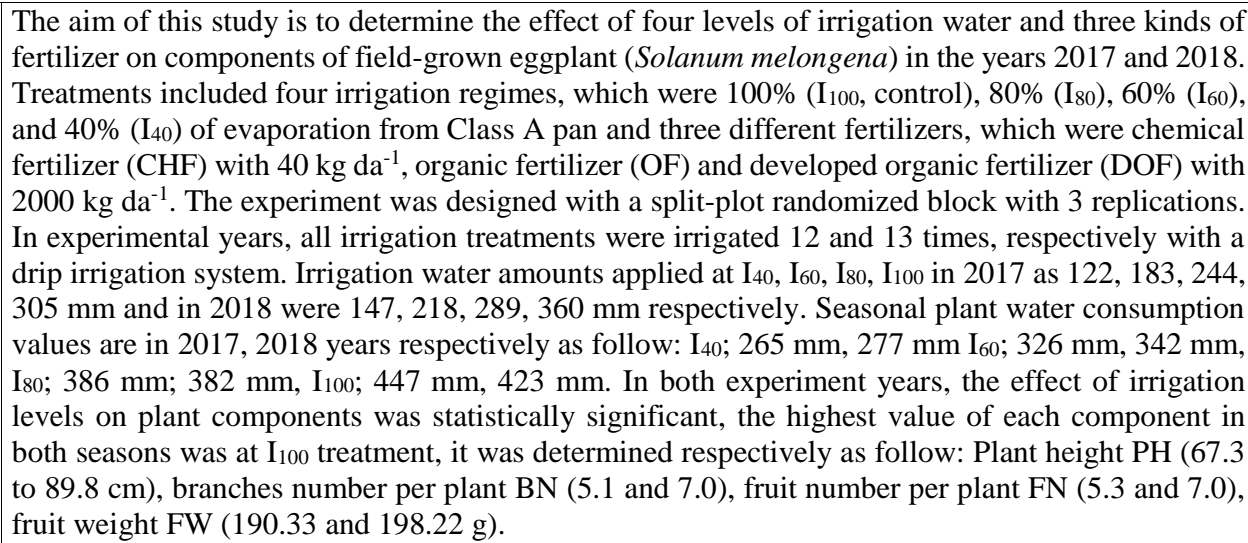 \\
\hline
\end{tabular}
(190.33 and $198.22 \mathrm{~g})$

a@mahmoudali1968@hotmail.com c@sgencoglan@ksu.edu.tr

\section{(iD) https://orcid.org/0000-0002-9000-8385} (i) https://orcid.org/0000-0002-7390-8365 b@gencoglan@ksu.edu.tr

iD https://orcid.org/0000-0002-4559-4354

\section{Introduction}

The limited water availability is declining for agriculture. All over the world because of rapid and larger population growth and the occurrence of drought in recent years and climate change and various human activities, access to food and water will be more difficult for countries and so agriculture will continue to be the most strategic sector of the two thousand years. Therefore, it is necessary to know relationships between the water consumption and plant components. Environmental protection and human health have recently become important factors when selecting food production systems. The wide usage of synthetic fertilizers in conventional production causes environmental pollution and land degradation (Robačer et al. 2016). In this context, it is necessary to determine the water consumption for eggplant and study the possibility of substituting organic fertilizers instead of chemical fertilizers. Mohawesh and Karajeh (2014) reported that water deficit reduced the growth of eggplant components. The common cause of the reduced vegetative growth of vegetables under water deficit conditions has been thought to be accelerated leaf senescence, as reported by Kirnak et al. (2002). Supplying plants with an optimum nutrient are primary for the production of top-quality fruit and good production levels (Hochmuth et al., 1993). Organic manure has played an essential role in agricultural production (improving soil fertility, crop yield, and quality). Organic fertilizers help to improve the soil organic matter content thereby, enhancing the utilization of fertilizer and increasing crop yields. Fertilization, not only can enhance crop yields and improve the quality, but also can help to improve soil fertility, and to maintain a good environment (Zhu 2000). Rosati et al. (2001) indicated that by increasing nitrogen supply, leaf area index, light interception and dry matter production of eggplant increased. Aminifard et al. (2010) evaluated the effect of four rates of nitrogen fertilizer on the growth and yield of eggplant and found that plant height, lateral stem number, leaf chlorophyll content, flower number, fruit weight, and fruit yield were all affected by nitrogen fertilizer. ElMiniawy (2015) concluded that irrigation of eggplants 
after the depletion of $70-75 \%$ of the available soil water plus the application of 100 or $150 \mathrm{~kg} \mathrm{~K}_{2} \mathrm{O} /$ feddan resulted in the highest vegetative growth and yield of eggplant and he indicated that irrigation after different depletion percentages of the available soil water significantly affected the eggplant vegetative growth characters, i.e. plant height, the number of branches and leaves, leaf area and fresh and dry weights of leaves. De et al. (1996) demonstrated that increasing $\mathrm{K}$ application for eggplant resulted in an increase of vegetative growth characters, i.e., plant height and crop growth rate as well as dry matter accumulation. During recent years' environmental protection and human health have become important factors when selecting production agricultural systems. From both conventional and organic production systems comes the need for sustainable practices to provide longterm soil fertility (Price and Norsworthy 2013). Inorganic fertilizers are known for their high cost and their negative environmental effects if managed poorly (Morris et al. 2007). Naderi and Bijanzadeh (2014) found that the application of organic amendments had the potential to increase the growth and chemical composition of two cultivars of safflower and therefore, might be a good alternative to chemical fertilizers. Louisa and Taguiling (2016) resulted that compost stimulates plant growth in terms of total height, number of leaves, fresh weight of plant biomass, and initial yield of eggplant (Solanum melongena). Organic fertilizer was obtained from microbial composting of organic agricultural and domestic wastes. It was found that organic fertilizer application for eggplant appeared to be superior to chemical fertilizers in terms of vegetative growth, fruit yield, and quality attributes. Organic fertilizer slightly shortened the vegetative period and improved the yield components and total marketable fruit yield. Organic fertilizer could be recommended as a full substitute for chemical fertilizers in eggplant production (Dinh Hoa 2008). Mechanochemical activation can be defined as a process being able to induce structural disorder through intensive grinding. In certain conditions, it may increase the chemical reactivity of the processed material (Tole et al. 2019). Organic farming minimizes the negative environmental effects compared to conventional production. It has been paid great attention to crop rotation and the use of organic fertilizers and soil conditioners in order to maintain soil fertility and organic matter content (Montemurro et al. 2013). Therefore, the objective of this study was to determine the effect of four levels of irrigation water and three kinds of fertilizer on plant components of field-grown eggplant (Solanum melongena).

\section{Materials and Methods}

The experiment was carried out in Bandirma in a field located at $40^{\circ} 16^{\prime} 44.4252^{\prime \prime}$ North and $28^{\circ} 4^{\prime} 18.9552^{\prime \prime}$ Eastern latitudes and longitudes and its altitude is $41 \mathrm{~m}$. The prevailing climate in Bandirma is the Mediterranean and the Black Sea climate. In addition, it is located on the transition zone of the terrestrial climate of the Balkans, the average lowest and highest temperature of 52-years are $5.3^{\circ} \mathrm{C}$ and $23.9^{\circ} \mathrm{C}$ with an annual mean of $14^{\circ} \mathrm{C}$. Rainfall, wind speed and relative humidity are $703.3 \mathrm{~mm}, 15 \mathrm{~km} \mathrm{~h}^{-1}$ and $73 \%$, respectively (Anonymous 2017).
Disturbed and undisturbed soil samples were taken from soil profile in 0-30, 30-60 and 60-90 cm soil layers (effective root depth of eggplant is $90 \mathrm{~cm}$ ), and then physical and chemical analyses were performed on these samples (Table 1). The $\mathrm{pH}$ of soil ranged from 8 to 8.1 , EC 0.76 to $0.84 \mathrm{dS} \mathrm{m}^{-1}$, organic matter $\% 0.68$ to $\% 1.2$, total nitrogen \% 0.090 to $\% 0.097$, phosphorus 1.44 to $1.69 \mathrm{~kg}$ $\mathrm{da}^{-1}$, potassium 59.8 to $83.8 \mathrm{~kg} \mathrm{da}^{-1}$, and volume weight (As) 1.28 to $1.31 \mathrm{~g} \mathrm{~cm}^{-3}$. The soil texture in the first layer $(0-30 \mathrm{~cm})$ is sandy clay; in the second layer $(30-60 \mathrm{~cm})$ sandy silt clay; the third layer $(60-90 \mathrm{~cm})$ silty.

Irrigation water pumped from the deep well near the experiment plot into a pool. Water samples were collected from the pool and then analyzed. The class of irrigation water is determined as $\mathrm{C}_{3} \mathrm{~S}_{1}$ (Table 2). In the experiment, eggplant cv. Karnaz variety was used as experiment material, this kind is suitable for open field cultivation. Fruits are 22-25 cm long, their tips are half-pointed, bright black, very high in browns, very homogeneous in fruits, and highly tolerant to Verticillium.

Table 1. Some physical and chemical properties of soil of the experiment area

\begin{tabular}{|c|c|c|c|}
\hline Profile $(\mathrm{cm})$ & $0-30$ & $30-60$ & $60-90$ \\
\hline $\mathrm{PH}$ & 8 & 8.1 & 8.1 \\
\hline $\mathrm{EC} \mathrm{dS} \mathrm{cm}^{-1}$ & 0.76 & 0.82 & 0.84 \\
\hline OM \% & 1.2 & 0.97 & 0.68 \\
\hline Totatal N\% & 0.094 & 0.09 & 0.097 \\
\hline $\mathrm{P}_{2} \mathrm{O}_{5} \mathrm{Kg} \mathrm{da}^{-1}$ & 1.69 & 1.44 & $<0.7$ \\
\hline $\mathrm{K}_{2} \mathrm{O} \mathrm{Kg} \mathrm{\textrm {Ka } ^ { - 1 }}$ & 83.8 & 67.9 & 59.8 \\
\hline As $\left(\mathrm{g} \mathrm{m}^{-3}\right)$ & 1.28 & 1.31 & 1.28 \\
\hline $\mathrm{WP}\left(\mathrm{P}_{\mathrm{w}}\right)$ & 20.4 & 19.8 & 20.3 \\
\hline $\mathrm{FC}(\mathrm{Pw})$ & 38.95 & 38.72 & 39.15 \\
\hline Sand \% & 30.6 & 30.7 & 28.6 \\
\hline Silt \% & 12.1 & 16 & 16 \\
\hline Clay \% & 57.3 & 53.3 & 55.4 \\
\hline Texture & Sandy Clay & Sandy Silt clay & Silty \\
\hline
\end{tabular}

As; volume weight of soil, FC; field capacity, OM; organic matter, WP; wilting point

Table 2. Chemical properties of the irrigation water

\begin{tabular}{|c|c|}
\hline Chemical property & The value \\
\hline $\mathrm{pH}$ & 7.3 \\
\hline $\mathrm{EC} \mu \mathrm{s} \mathrm{cm}-1$ & $1052 c_{3}$ \\
\hline $\mathrm{K}+\mathrm{me} \mathrm{L}-1$ & 0.06 \\
\hline $\mathrm{Ca}++$ me L-1 & 4.36 \\
\hline $\mathrm{Mg}++$ me L-1 & 3.99 \\
\hline $\mathrm{Na}+$ me L-1 & 2.51 \\
\hline $\mathrm{CO} 3$ - meL-1 & -- \\
\hline HCO3- me L-1 & 6.18 \\
\hline Cl- me L-1 & 1.85 \\
\hline $\mathrm{SO} 4$ - me L-1 & 2.89 \\
\hline SAR & $1.23 \mathrm{~s}_{1}$ \\
\hline RSC me L-1 & -- \\
\hline PS me L-1 & 3.295 \\
\hline
\end{tabular}

SAR; sodium absorption rate, RSC; residual sodium carbonate, PS; potential salinity.

In the study, treatments were selected to determinate effect of four different irrigation levels and three different fertilizers on the components of eggplant. Irrigation and fertilizer treatment were planned in the main and subparcels, respectively and formed in a split-plots 
randomized block design with three replicates. Irrigation treatments were created as $100 \%\left(\mathrm{I}_{100}\right.$, control $), 80 \%\left(\mathrm{I}_{80}\right)$, $60 \%\left(\mathrm{I}_{60}\right)$ and $40 \%\left(\mathrm{I}_{40}\right)$ of total amount of water evaporated from Class A Pan, and irrigations were done when total evaporation from Class A Pan was $40 \mathrm{~mm}$ or more. Fertilizer treatments were organic fertilizer (OF) with 2000 $\mathrm{kg} \mathrm{da}^{-1}$, developed organic fertilizer (DOF) with $2000 \mathrm{~kg}$ $\mathrm{da}^{-1}$ and chemical fertilizer (CHF) with $40 \mathrm{~kg} \mathrm{da}^{-1}$, which was control for fertilizers. $\mathrm{CHF}$, called compound fertilizers, contains major elements of N, P, K (15-15-15 + $20 \mathrm{SO}_{3}$ ). OF and DOF consists of $75 \%$ cow manure and $25 \%$ chicken manure, prepared in an aerobic fermentation method. The difference between Normal Organic fertilizer (OF) and developed organic fertilizer (DOF) is that $20 \%$ of developed organic fertilizer prepared by a mechanical activation process using a high energy ball milling machine (Ibrahim et al., 2010). OF and DOF were granulated up to grain size of 1 to $8 \mathrm{~mm}$ to make it slow-release organic fertilizers. In both organic fertilizers, OM content is $33 \%$, the humic + folvic content is $18.4 \%$ and the $\mathrm{pH}$ is 7.4 (Table 3).

Table 3. Chemical properties of organic fertilizers (OF and DOF)

\begin{tabular}{l|c}
\hline \multicolumn{1}{c|}{ Chemical property } & The value \\
\hline $\mathrm{pH}$ & 7.4 \\
OM. (\%) & 32.9 \\
Moisture (\%) & 10.7 \\
Humik+folvik (\%) & 18.4 \\
Total N (\%) & 1.88 \\
$\mathrm{P}_{2} \mathrm{O}_{5}(\%)$ & 2.04 \\
$\mathrm{~K}_{2} \mathrm{O}(\%)$ & 1.2 \\
\hline
\end{tabular}

In the both research years, the experimental area was tilled, plots were created, and fertilizers were applied and then fertilizer mixed into soil by hoeing. After that, the drip irrigation system was installed, eggplant seedlings were planted in the two research years on 02.06.2017 and 22.05.2018 according to the experiment plan. The spacing between plants rows was $70 \mathrm{~cm}$, the spacing within rows was $40 \mathrm{~cm}$, and each parcel with 120 plants contained 6 rows, one of which has 20 plants. Plots size was $8 \mathrm{~m} \times 4.2$ $\mathrm{m}\left(33.6 \mathrm{~m}^{2}\right)$. The total number of the plots was 36 , space between the plots was $2 \mathrm{~m}$, the total area of the experiment was $2380.8 \mathrm{~m}^{2}$. Doing every irrigation before 24 hours, soil samples from layers of $0-30,30-60$ and $60-90 \mathrm{~cm}$ were taken by auger to determine the moisture content in the soil profiles, and dried at $105^{\circ} \mathrm{C}$ in the oven for 24 hours. Evapotranspiration (ET) was calculated with the water balance equation (Eq. (1)) (Garrity et al. 1982; James et al. 1982; Gençoğlan et al. 2006; Gençoğlan and Kiraç 2008):

$\mathrm{ET}=\mathrm{I}+\mathrm{P} \pm \mathrm{DSW}-\mathrm{Dp}-\mathrm{Rf}$

Where ET is the evapotranspiration ( $\mathrm{mm})$, I the amount of irrigation water applied (mm) I the amount of irrigation water applied (mm) which is calculated depending on evaporation from the Class A pan, $\mathrm{P}$ the precipitation (mm), DSW the soil water content change (mm) before every irrigation in the $60 \mathrm{~cm}$ soil profile (effective rooting depth of eggplant), Dp the deep percolation (mm), and Rf the amount of runoff $(\mathrm{mm})$. Since the amount of irrigation water was controlled, run off was assumed to be zero.
Monitoring soil water content in the plots revealed that deep percolation was negligible below $60 \mathrm{~cm}$ depth.

Irrigation was applied when the amount of water evaporating from the Class A Pan is equal to or greater than $40 \mathrm{~mm}$. In the calculation of volume of irrigation water, the method given by Allen et al. (1998) was used as followed: Crop evapotranspiration is calculated directly using Equation 2.

$\mathrm{ETc}=\mathrm{K}_{\mathrm{cp}} \times \mathrm{E}_{\mathrm{pan}}$

Where ETc is the crop evapotranspiration $(\mathrm{mm}), \mathrm{Kcp}$ is crop-pan coefficient and $\mathrm{E}_{\mathrm{pan}}$ is pan evaporation $(\mathrm{mm})$. Four crop-pan coefficients, Kcp1 $=0.40, \mathrm{Kcp} 2=0.60$, $\mathrm{Kcp} 3=0.80$ and $\mathrm{Kcp} 4=1.00$ were used to determine response of eggplant to different level of water. For this aim, a screened Class A Pan (1210 mm in diameter and 250 $\mathrm{mm}$ depth and made of Galvanized metal with $0.8 \mathrm{~mm}$ thickness) was located on wooden base next to experimental field, surrounding by vegetation but no shadowing (Doorenbos and Pruitt 1977).

During the growing season to determine fruit number for per plant $(\mathrm{FN})$ and fruit weight $(\mathrm{FW})$, the harvested fruits were counted and weighted from randomly selected and marked 5 plants from every row in each plot and averaged in both experiment years and finally, averages of FWs were found dividing total FW by total FN. At the end of the growing season 5 plants selected randomly in each parcel, their heights $(\mathrm{PH})$ and branches number $(\mathrm{BN})$ were determined and their averages were found. Analysis of variance was performed on data of $\mathrm{PH}, \mathrm{BN}, \mathrm{FN}$ and $\mathrm{FW}$. The level of significant difference (LSD at $\mathrm{P}<0.05$ ) was used in ANOVA to test the effect of irrigation and fertilizers treatments on different response variables (Steel and Torrie 1980).

\section{Results and Discussion}

Applied irrigation water (I) and Evapotranspiration (ET)

In both experimental years, eggplant seedlings were planted on 02 June 2017 and 22 May 2018 and also to establish seedlings, irrigation of $50 \mathrm{~mm}$ was applied to all experimental plots. Then, scheduled irrigations started based on the amount of evaporation from Class A Pan when total eveporation amount was equal to or more than $40 \mathrm{~mm}$. In two growing season, total pan evaporation were measured as 579 and $599 \mathrm{~mm}$, and precipitation were 143 and $86 \mathrm{~mm}$, and treatments were irrigated 12 and 13 times. Total amounts of applied irrigation water changed between 122 and $305 \mathrm{~mm}$ in 2017, and between 147 and $360 \mathrm{~mm}$ in 2018. ET ranged from 264 to $447 \mathrm{~mm}$ in the first year and $217 \mathrm{~mm}$ to $436 \mathrm{~mm}$ in the second year (Table 4). Ertek et al. (2006) reported that the amount of irrigation water ranged from 372 to $689 \mathrm{~mm}$, while the average plant water consumption values vary between 420 and $689 \mathrm{~mm}$. Ayas (2017) concluded that irrigation water and evapotranspiration of eggplant ranged from 85 to $464 \mathrm{~mm} 170$ to $472 \mathrm{~mm}$. Şenyiğit et al. (2011) found the amount of the applied irrigation water and evapotranspiration (ET) ranged between 95.2 and 238.7 $\mathrm{mm}$, and from 93.1 to $466.3 \mathrm{~mm}$ in greenhous. Çolak et al. (2017) reported that the total amount of the applied irrigation water changed between $243 \mathrm{~mm}$ and $495 \mathrm{~mm}$ among the surface drip irrigated treatments and it varied from $228 \mathrm{~mm}$ 
to $446 \mathrm{~mm}$ in the subsurface drip plots. He found that evapotranspiration (ET) of eggplant was between 339 and $543 \mathrm{~mm}$ in surface drip system treatments and 306 and 495 $\mathrm{mm}$ in subsurface drip system treatments. Lovelli et al. (2007) found that eggplant evapotranspiration (ET) varied from 339 to $543 \mathrm{~mm}$ and from 306 to $495 \mathrm{~mm}$ in surface drip and from 306 to $495 \mathrm{~mm}$ in subsurface drip treatments, respectively. The results were obtained by Ayas (2017), Çolak et al. (2017) and Şenyiğit et al. (2011) are compatible with this reserch results. However, the results obtained by Ertek et al. (2006) are somewhat different due to different irrigation management and climatic conditions in the research area. About the effect of fertilizer on ET, no effect has been noticed, because the same amounts of water have been applied to all fertilizer treatments in every irrigation treatment depending on class A pan evaporation.

\section{Some Eggplant Components}

Results, presented in Table 5, showed the effect of deficit irrigation on eggplant components such as plant height, number of branches, fruit number per plant and average of fruit weight.

Plant height ( $p H)$ : $\mathrm{PH}$ was ranged from 67.3 to $89.8 \mathrm{~cm}$ at $\mathrm{I}_{100}$ irrigation treatment the next was $\mathrm{I}_{80}(60.7$ and 78.6 $\mathrm{cm})$ then $\mathrm{I}_{60}(58.4$ and $67.5 \mathrm{~cm})$ and $\mathrm{I}_{40}(54.7$ and $57.8 \mathrm{~cm})$ (Table 5). Also among the fertilizer treatment the highest ones were measured from DOF and then CHF while the lowest one was from OF (Figure 1). The effect of irrigation and fertilizer treatment, and irrigation $\times$ fertilizer interaction on $\mathrm{PH}$ values was statistically significant $(\mathrm{P}<0.05)$ in 2017. In 2018, it was found to be significant for irrigation and fertilizer treatment $(\mathrm{P}<0.05)$, but not significant at irrigation $\times$ fertilizer interaction $(\mathrm{P}>0.05)$. Gaveh et al. (2011) also concluded that irrigation affected significantly on PH in the dry season. The heights of plants irrigated with water of $80 \%$ were the shortest among the 3 irrigation treatments. $120 \%$ irrigation regime resulted in a highly significant increase in plant height. Abdrabbo (2017) reported that the highest $\mathrm{PH}$ was $87.8 \mathrm{~cm}$ in $\mathrm{I}_{100}$ irrigation treatment. Bilibio et al. (2013) demonstrated that reducing a crops evapotranspiration beyond a certain level would have a significant impact on the height of eggplants. The least PH could be attributed to the non-availability of adequate moisture, which has a significant impact on the vegetative growth of eggplants. El-Miniawy (2015) reported that eggplant $\mathrm{PH}$ ranges from 59.3 to $77.3 \mathrm{~cm}$ depending on increase of irrigation and potassium application. Mirdad (2011) found that PH ranges from 59.53 to $100.21 \mathrm{~cm}$ depending on irrigation interval and nitrogen rate. Amiri et al. (2012) illustrated that eggplant $\mathrm{PH}$ ranges from 87.4 to $125.6 \mathrm{~cm}$ depending on irrigation interval and nitrogen rate. The results obtained in this study are parallel with the results of the studies of Lovelli et al. (2007), Ertek et al. (2006). It was observed that reduction in PH measured when eggplant was subjected to deficit irrigation $\left(\mathrm{I}_{40}\right)$.

Table 4. Applied irrigation water amounts and plant water consumption (ET)

\begin{tabular}{l|cccccc}
\hline \multirow{2}{*}{$\begin{array}{c}\text { Irrigation } \\
\text { Treatment }\end{array}$} & $\begin{array}{c}\text { Number of } \\
\text { irrigation }\end{array}$ & $\begin{array}{c}\text { Irrigation water } \\
(\mathrm{mm})\end{array}$ & $\begin{array}{c}\text { ET } \\
(\mathrm{mm})\end{array}$ & $\begin{array}{c}\text { Number of } \\
\text { irrigation }\end{array}$ & $\begin{array}{c}\text { Irrigation } \\
\text { water }(\mathrm{mm})\end{array}$ & $\begin{array}{c}\text { ET } \\
(\mathrm{mm})\end{array}$ \\
\hline $\mathrm{I}_{40}$ & 12 & 122 & 264 & 13 & 147 & 217 \\
$\mathrm{I}_{60}$ & 12 & 183 & 325 & 13 & 218 & 292 \\
$\mathrm{I}_{80}$ & 12 & 244 & 386 & 13 & 289 & 365 \\
$\mathrm{I}_{100}$ & 12 & 305 & 447 & 13 & 360 & 436 \\
\hline
\end{tabular}

Table 5. Some plant growth and fruit variables result

\begin{tabular}{l|cccccccc}
\hline Year & \multicolumn{9}{|c}{2017} & \multicolumn{3}{c}{2018} \\
\hline Irrigation treatment & $\mathrm{I}_{100}$ & $\mathrm{I}_{80}$ & $\mathrm{I}_{60}$ & $\mathrm{I}_{40}$ & $\mathrm{I}_{100}$ & $\mathrm{I}_{80}$ & $\mathrm{I}_{60}$ & $\mathrm{I}_{40}$ \\
Plant height $(\mathrm{cm})$ & $67.3^{(\mathrm{a})}$ & $60.7^{(\mathrm{b})}$ & $58.4^{(\mathrm{c})}$ & $54.7^{(\mathrm{d})}$ & $89.8^{(\mathrm{a})}$ & $78.6^{(\mathrm{b})}$ & $67.5^{(\mathrm{c})}$ & $57.8^{(\mathrm{d})}$ \\
Branch number per plant & $5.1^{(\mathrm{a})}$ & $4.6^{(\mathrm{b})}$ & $3.8^{(\mathrm{c})}$ & $3.8^{(\mathrm{c})}$ & $7.0^{(\mathrm{a})}$ & $6.4^{(\mathrm{b})}$ & $6.0^{(\mathrm{c})}$ & $5.6^{(\mathrm{d})}$ \\
Fruit number per plant & $5.3^{(\mathrm{a})}$ & $4.5^{(\mathrm{b})}$ & $3.9^{(\mathrm{c})}$ & $3.7^{(\mathrm{c})}$ & $7.0^{(\mathrm{a})}$ & $6.5^{(\mathrm{b})}$ & $6.0^{(\mathrm{c})}$ & $5.6^{(\mathrm{c})}$ \\
Average of fruit weight $(\mathrm{g})$ & $190.3^{(\mathrm{a})}$ & $180.8^{(\mathrm{b})}$ & $176.9^{(\mathrm{c})}$ & $164.9^{(\mathrm{d})}$ & $198.2^{(\mathrm{a})}$ & $189.7^{(\mathrm{b})}$ & $185.8^{(\mathrm{c})}$ & $158.3^{(\mathrm{d})}$ \\
\hline
\end{tabular}

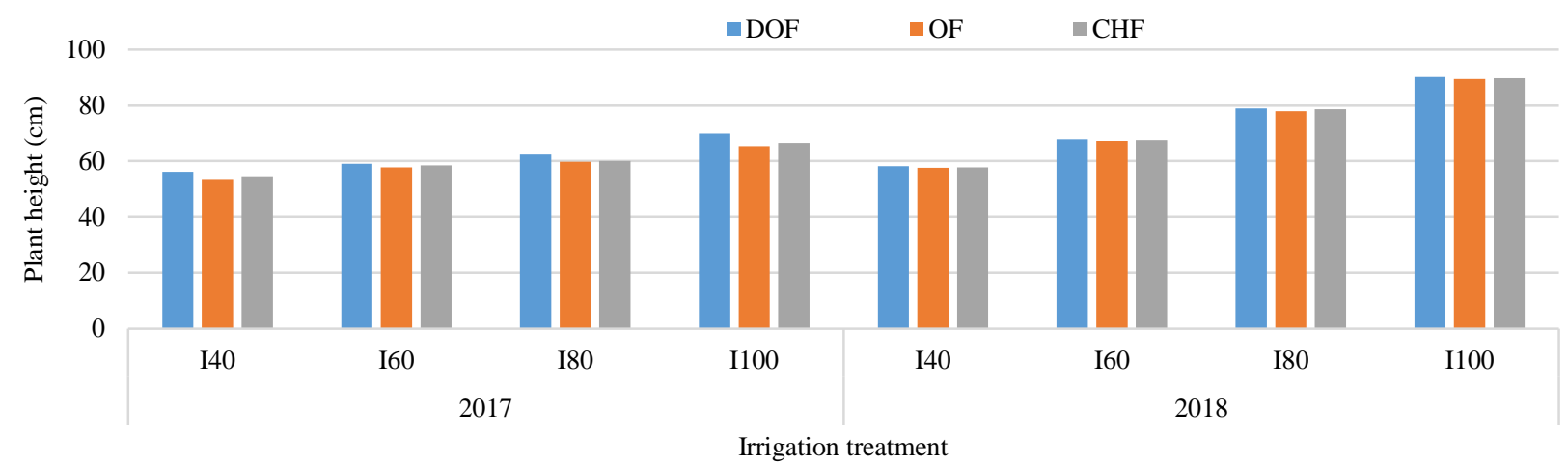

Figure 1. Effect of irrigation level and fertilizer on plant height 


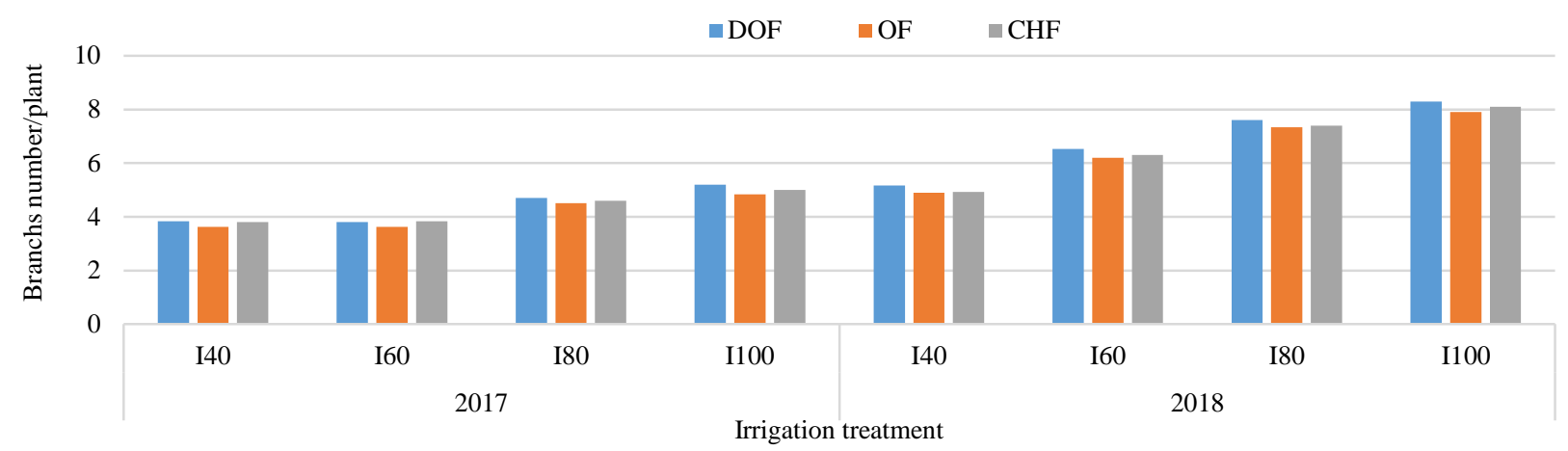

Figure 2. Effect of irrigation level and fertilizer on BN

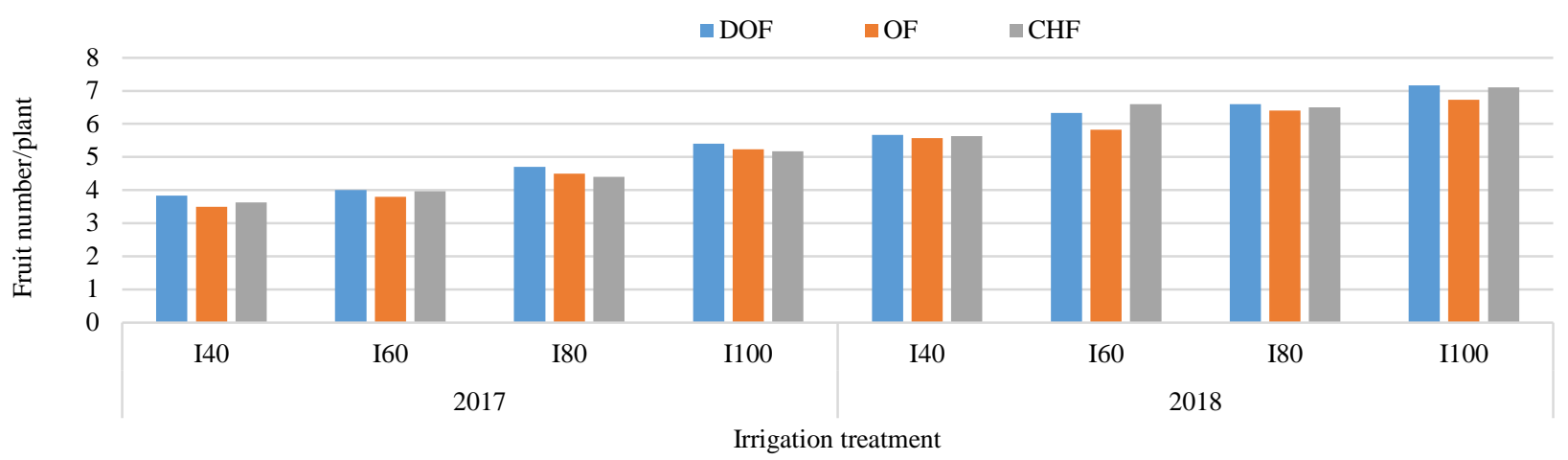

Figure 3. Effect of irrigation level and fertilizer on number of fruit per plant

Branch number per plant $(B N)$ : In both season of the experiment it was found that the highest average $\mathrm{BN}$ were at $\mathrm{I}_{100}$ as 5.1 and 7.0 respectively, then at $\mathrm{I}_{80}$ as 4.6 , and 6.4 then at $\mathrm{I}_{60}$ as 3.8 and 6.0 while the lowest ones was 3.8 and 5.6 in $\mathrm{I}_{40}$ irrigation treatment, respectively (Table 5). For the effect of fertilizer treatment; the maximum average $\mathrm{BN}$ was at DOF fertilizer treatment and the minimum was at OF fertilizer treatment (Figure 2). The effect of irrigation treatments on average $\mathrm{BN}$ in 2017 and 2018 was statistically significant $(\mathrm{P}<0.05)$. This means that the $\mathrm{BN}$ increased as amount of irrigation water increased from $\mathrm{I}_{40}$ to $\mathrm{I}_{100}$. BN number is very important in terms of fresh yield. The effect of fertilizer treatment and irrigation $\mathrm{X}$ fertilizer interaction on average $\mathrm{BN}$ was insignificant $(\mathrm{P}<0.05)$. The results obtained in this study are parallel with the studies of Ertek et al. (2006). Also El-Miniawy (2015) found that $\mathrm{BN}$ ranged from 5.0 to 8.2 by application of different level of irrigation and four level of potassium fertilizer on eggplant.

Fruit number $(F N)$ : At the experiment maximum FN per plant determined at $\mathrm{I}_{100}$ irrigation treatment (5.3 and 7.0, respectively) followed by $\mathrm{I}_{80}\left(4.5\right.$ and 6.5) then $\mathrm{I}_{60}(3.9$ and 6.0) while the minimum was got from $\mathrm{I}_{40}$ (3.7 and 5.6) in both season respectively as seen in Table 5. For the effect of fertilizer treatment on average FN per plant; in every irrigation treatment the highest average was at DOF fertilizer treatment and the lowest was at OF fertilizer treatment (Figure 3). The effect of irrigation treatment, on average FN per plant values in 2017 and 2018 was statistically significant $(\mathrm{P}<0.05)$ and but the effect of fertilizer treatment and irrigation $\mathrm{X}$ fertilizer interaction on average FN per plant was not statistically significant. The results obtained in this study are agreement with the results of Çolak et al. (2017), Ertek et al. (2006) and Şenyiğit et al. (2011).
Fruit weight $(F W)$ : For the average of fruit weight $\mathrm{FW}$ it was obtained that the highest average was at $\mathrm{I}_{100}$ treatment as 190.33 and $198.22 \mathrm{~g}$ followed by $\mathrm{I}_{80}(180.8$ and $189.7 \mathrm{~g}), \mathrm{I}_{60}(176.9$ and $185.8 \mathrm{~g})$ and $\mathrm{I}_{40}(164.9$ and $158.3 \mathrm{~g}$ ) that of which was minimum (Table 5). For the effect of fertilizer treatment on average of fruit weight; in every irrigation treatment the highest was at DOF fertilizer treatment and the lowest yield was at OF fertilizer treatment. The effect of irrigation treatment, on average fruits weight in 2017 and 2018 was statistically significant $(\mathrm{P}<0.05)$. Increase in FW is also one of the most significant factors because of affecting yield and it means that treatments with high FW give the highest yield. The effect of fertilizer treatment on average of FW was statistically insignificant. The results from this study are parallel with the studies of Şenyiğit (2011) and Ayas (2017). Çolak et al. (2017) reported that average FW changed between 59.53 and $100.21 \mathrm{~g}$ depending on irrigation amount. It can be concluded that plants providing with adequate moisture may enhance physiological processes. Moreover, it increases translocation of metabolites which in turn, increased the accumulation of organic compounds in the plants (Owusu-Sekyere and Andoh, 2010).

\section{Conclusion}

Under Bandirma climatic conditions in 2017-2018 growing years, at four irrigation levels applied by drip irrigation system, and three fertilizers, it was significant differences between the irrigation treatments in plant growth and fruit variables $(\mathrm{P}<0.05)$. But no significant differences were found between $\mathrm{I}_{100}$ and $\mathrm{I}_{80}$ treatments in plant fresh weight in two experiment years. The highest plant growth and fruit variables were obtained from $\mathrm{I}_{100}$ irrigation treatment in both season respectively as follow: PFW; plant 
fresh wieght $\left(4216,3906 \mathrm{~kg} \mathrm{da}^{-1}\right), \mathrm{PH}$; plant hight $(67.3,89.8$ $\mathrm{cm}), \mathrm{BN}$; branch number $(5.1,7.0)$, FN; fruit number $(5.3$, 7.0), FW; fruit wieght $(190.33,198.22 \mathrm{~g})$. The data obtained from $I_{100}$ and $I_{80}$ treatments were taken place in the same group by LSD test. Therefore, it can be said $\mathrm{I}_{80}$ most suitable irrigation schedule for eggplant. No significant effect noticed between fertilizers treatments in two experiment years $(\mathrm{P}>0.05)$, nevertheless it can be said that chemical fertilizer can be replaced by developed organic fertilizer because the highest yield was obtained from DOF fertilizer treatment, at the other side to avoiding the health and environmental damage of chemical fertilizer.

\section{Acknowledgment}

We would like to thank Yeşil Hayat Makine ve Sanayi AŞ. Company for supplying the materials and fertilizers of this research.

\section{References}

Abdrabbo MAA, Saleh SM, Hashem FA. 2017. Eggplant Production under Deficit Irrigation and Polyethylene Mulch. Egypt journal of applied sciences 32 (7): 148-161.

Allen RG, Pereira LS, Raes D, Smith M. 1998. Crop Evapotranspiration Guidelines for Computing Crop Water Requirements, Irrigation and Drainage. Paper No: 56, FAO, Rome, p. 300.

Aminifard M, Aroiee H, Fatemi H, Ameri A, Karimpour S. 2010. Responses of Eggplant (Solanum melongena L.) to Different Rates of Nitrogen under Field Conditions. Journal of Central European Agriculture 11 (4): 453-458.

Amiri E, Gohari A, Esmailian Y. 2012. Effect of Irrigation and Nitrogen on Yield, Yield Components and Water Use Efficiency of Eggplant. African Journal of Biotechnology 11(13): 30703079. Available online at http://www.academicjournals.org/AJB DOI: 10.5897/AJB11.2450 ISSN 1684-5315 (C) 2012 Academic.

Anonymous. 2017. http://www.bandirma.gov.tr/iklim-vecografi-konum.

Ayas S. 2017. The Effects of Irrigation Regimes on the Yield and Water Use of Eggplant (Solanum melongena L.) Toprak Su Dergisi 6 (2): 49-58.

Bilibio C, Hensel O, Carvalho JA. 2013. Yield of Eggplant Submitted to Different Water Tensions on Soil. StuttgartHohenheim Pp. 17-19.

Çolak YB, Yazar A, Çolak İ, Akça H, Duraktekin G. 2017. Evaluation of Crop Water Stress Index (CWSI) for Eggplant Undervarying Irrigation Regimes Using Surface and Subsurface Drip Systems. Agriculture and Agricultural Science Procedia 4(1): 372 - 382 .

De C, Jun Jie H, Kui C. 1996. Studies on Fertilizer Application Levels of Seedling Stage of Eggplant Raised with Mixed Media. China Vegetables 4: 16-18.

Dinh Hoa Vu. 2008. Effect of Organic Fertilizer on Fruit Yield and Quality of Eggplant (Solanum melongena L.). In AGRIS since 13(3): 137-142.

Doorenbos J, Pruitt WO. 1977. Guidelines for Predict of Water Requirement. Irrigation and Drainage No. 24, FAO, Rome p. 144.

El-Miniawy S. 2015. Growth and Yield of Eggplant Grown under Drought Stress Conditions and Different Potassium Fertilizer Rates. Middle East Journal of Agriculture Research 04(04): 1113-1124.

Ertek A, Sensoy S, Kucukyumuk C, Gedik I. 2006. Determination of Plant-pan Coefficients for Field-Grown Eggplant (Solanum melongena L.) Using Class, A pan Evaporation values. Agricultural Water Management (85): 58-66.
Garrity PD, Watts DG, Sullivan CY, Gilley JR. 1982. Moisture Deficits and Grain Sorghum Performance: Evapotranspiration-yield Relationships. Agronomy-Journal 74(5): 815-820.

Gaveh EA, Timpo GM, Agodzo SK, Shin DH. 2011. Effect of Irrigation, Transplant Age and Season on Growth, Yield and Irrigation Water Use Efficiency of the African Eggplant. Horticulture, Environment, and Biotechnology 52(1): 13-28.

Gençoğlan C, Altunbey H, Gençoğlan S. 2006. Response of Green Bean $(P$. Vulgaris L.) to Subsurface Drip İrrigation and Partial Root Zone-Drying Irrigation. Agricultural Water Management 84(3): 274-280.

Gençoğlan C, Kiraç AM. 2008. Damla sulama yöntemi ile uygulanan bazı sulama tekniklerinin tam bodur elma ağaçlarında su kullanımına ve topraktaki tuz birikimi. üzerine olan etkileri. DSI, Sulama Tuzluluk Toplantısı. Şanlıurfa, Turkey pp: 177-189, 12-13,

Hochmuth GJ, Hochmuth RC, Donley ME, Hanlon EA. 1993. Eggplant yield in response to potassium fertilization in sandy soil. Hort. Science, 28(10): 1002-1005.

Ibrahim SS, El-Midany AA, Boulos TR. 2010. Effect of Intensive Mechanical Stresses on Phosphate Chemistry as A Way to Increase Its Solubility for Fertilizer Application. Physicochemical Problems of Mineral Processing 44- 79-92.

James DW Hanks RJ, Jurinak JJ. 1982. Modern Irrigation Soils. John Wiley and Sons. New York pp 235.

Kirnak H, Tas 'I, Kaya C, Higgs D. 2002. Effects of Deficit Irrigation on Growth, Yield and Fruit Quality of Eggplant under Semi-Arid Conditions. Australian Journal of Agricultural Research 53: 1367-1373.

Louisa MA, Taguiling G. 2016. Response of Some Vegetable Plants to Green Biomass Enriched Compost. IOSR Journal of Agriculture and Veterinary Science (IOSRJAVS). 9(5):67-74 [e-ISSN: 2319-2380] [p-ISSN: 2319-2372] Available: www.iosrjournals.org.

Lovelli S, Perniola M, Ferrara A, Tommaso T. 2007. Yield response factor to water (ky) and water use efficiency of Carthamus Tinctorius L. And Solanum melongena L. Agricultural Water Management (92):73-80.

Mirdad Z. 2011. Vegetative Growth Yield and Yield Components of Eggplant (Solanum melongena L.) as Influenced by Irrigation Intervals and Nitrogen Levels. Environmental and Arid Agricultural Science 22(1): 31-49.

Mohawesh O, Karajeh M. 2014. Effects of Deficit Irrigation on Tomato and Eggplant and Their Infection with the Root-Knot Nematode under Controlled Environmental Conditions. Archives of Agronomy and Soil Science 60(8): 1091-1101.

Morris M, Kelly VA, Kopicki RJ and Byerlee D. 2007. Fertilizer Use in African Agriculture: Lessons learned and good practice guidelines. Washington, DC: The World Bank. The Rain Forest Area of Nigeria. Applied Tropical Agriculture 5: 20-23.

Montemurro F, Fiore A, Campanelli G, Tittarelli F, Ledda L, Canali S. 2013. Organic fertilization, green manure, and vetch mulch to improve organic zucchini yield and quality. HortScience 48: 1027-1033.

Naderi R, Bijanzadeh E. 2014. Organic amendments and nitrogen effects on growth and chemical composition of two cultivars of safflower (Carthamus tinctorius L.) Australian Journal of Crop Science 8(4): 577-581.

Owusu-Sekyere JD, Andoh J. 2010. Assessment of Deficit Irrigation on the Growth and Yield of Some Vegetable Crops. Unpublished thesis. Department of Agricultural Engineering, University of Cape Coast, Ghana.

Price AJ, Norsworthy K. 2013. Cover crops for Weed Management in Southernreduce-tillage vegetable cropping systems. Weed Technol 27: 212-217.

Robačer M, Canali S, Lakkenborg Kristensenc H, Baveca F, Grobelnik Mlakara S, Jakop M, Baveca M. 2016. Cover Crops in Organic Field Vegetable Production. Journal Scientia Horticulturae 208: 104-110. 
Rosati A, Badeck FW, Dejong TM. 2001. Estimating Canopy Light Interception and Absorption Using Leaf Mass Per Unit Leaf Area in Solanum melongena. Annals of Botany 88: 101109

Şenyiğit U, Kadayifci A, Ozdemir FO, OZ H, Atilgan A. 2011. Effects of Different Irrigation Programs on Yield and Quality Parameters of Eggplant (Solanum melongena L.) Under Greenhouse Conditions Department of Agricultural Structure and Irrigation, Faculty of Agriculture, African Journal of Biotechnology 10(34): 6497-6503.
Steel RGD, Torrie JH. 1980. Principles and Procedures of Statistics, seconded. McGraw-Hill, New York.

Tole I, Habermehl-Cwirzen K and Cwirzen A. 2019. Mechanochemical Activation of Natural Clay Minerals: An Alternative to Produce Sustainable Cementitious Binders. Mineralogy and Petrology 113: 449-462.

Zhu ZL. 2000. Farmland in nitrogen loss and countermeasures. Journal of Soil and Environment 9(1): 1-6. 